\title{
TEACHING THE ART OF PLAYING WITH CAREER-COUPLING RELATIONSHIPS IN THE VIRTUOSO WORLD
}

\author{
Izabela Wagner
}

\begin{abstract}
Socialization of young virtuosos in the milieu of soloists involves creating and entertaining particular ties. Those ties, which mix the private and professional lives of teacher, student, and parents, offer an interesting avenue for studying socialization. I examine one relationship crucial to the virtuoso's career: the close-knit relationship between teacher and student, and the effect each one has on the career of the other. I define this process as "career coupling," where those involved build their careers together. I base this analysis on ethnographic research of the careers of elite musicians.
\end{abstract}

\section{INTRODUCTION}

This particular work represents one of the first studies to closely examine an elite circle of violin virtuosos: musicians who aspire to become or already are soloists. I use the category "soloist" according to D.L. Westby's (1960, p. 225) definition to mean "a self-employed entrepreneur, a free agent"

Studies in Symbolic Interaction, Volume 35, 147-171

Copyright (C) 2010 by Emerald Group Publishing Limited

All rights of reproduction in any form reserved

ISSN: 0163-2396/doi:10.1108/S0163-2396(2010)0000035012 
musician that can choose to play, teach, conduct, or engage in other activities in the classical music world. I draw on ethnographic data on the art world (Becker, 1982) of virtuosos to analyze important processes of professional socialization. I contend that interactionism offers valuable tools for learning about specific conventions and particular relationships that are a part of the music profession, and in this study, to articulate a concept that I call "career coupling."

\section{CAREER COUPLING IN THE VIRTUOSO WORLD}

The mentor-disciple relationship is a topic that has been deeply studied, especially within the university environment and within the milieu of life-science researchers (Wagner, 2006b, 2010b), as well as other social environments in which reputations and careers are built through peer opinion. In these fields, mentor-disciple pairing constitutes one of the most important professional relationships. However, studies of this relationship have focused primarily on the impact of a professor's sponsorship and education in the student's career (Reskin, 1979; Ziman, 1987), or an examination of the personal mentor-disciple relationship (Burawoy, 2005; Schnaiberg, 2005). Several publications devoted to the stages of socialization took into account the aspect of professional training - the mentor's impact on the disciple's education (Traweek, 1988; Campbell, 2003; Adler \& Adler, 2005; Ferrales \& Fine, 2005; Shulman \& Silver, 2003; Schnaiberg, 2005). Although numerous articles about mentoring relationships focus on the impact of mentors on their disciples' careers, few, if any, studies address the influence of disciples' careers on the careers of their mentors, or the interaction between both mentor and disciple's careers.

Career coupling refers to the development of intensive and enduring relationships between individuals representing two (or more) careers. This interactive process explains the professional and parallel routes of two or more individuals who cooperate - each within their own specialty - during a period long enough for them to change each other's professional positions (Wagner, 2006b). Partners acquire prestige through their respective career partners in music and other elite occupational environments in which the main goal of the professional activity is the attainment of a high level of performance. Individuals in a career couple therefore perceive the reputation of each partner in relation to their own reputation and career trajectory. 
In the soloist world, students become well known for their relationship with teachers, and teachers for their mentoring relationship with students. To explain the effect of a close coupling relationship between the career of the virtuoso and the teacher, I use the interactionist concept of career (Becker \& Strauss, 1956; Becker, 1970; Hughes, 1971). This concept defines the course of professional life as a series of stages. At each stage the actors have different interactions with significant persons in their professional environment. Because an adult violinist's career depends strongly on educational pedigree, his or her mentoring relationships play an integral part of a soloist's career.

\section{METHODS}

For nine years, I was a participant observer in the virtuoso world and played a number of different membership roles. First, I was the parent of a young soloist, and thus assumed the "parent-as-researcher" role (Adler \& Adler, 1991). My family also hosted more than 20 young musicians, who lived alone or with their parents, for various periods of time in our home, the durations of which ranged from two weeks to one year. I was also a casual observer at master classes, witnessing a famous violin teacher at work in mentoring his students. I was also a translator, a concert organizer, and a member of a young talents' support association.

In my continuous fieldwork (Duneier, 2007), I closely observed the lives of 90 violinists, and had frequent contact with 9 teachers and 30 parents of young virtuosos. Between 1997 and 2004, I conducted more than 100 formal, semistructured interviews. Because of my strong attachment to this field, I was able to conduct several hundred informal interviews lasting $2-4.5 \mathrm{~h}$. I recorded the interviews of 40 students, 11 teachers, 14 parents, 4 violinmakers, 3 accompanists, 2 concert organizers, 2 conductors, 4 teacher's assistants, and 1 sound engineer. Some of my respondents agreed to follow up recorded interviews with me, usually two or three times (with at least one-year intervals between interviews). 1

I carried out my research in six different countries: mainly in France, Poland, Germany, and sporadically in Italy, Spain, and the USA. I conducted the interviews in French, Russian, Polish, and English. Although I conducted this research activity in numerous foreign countries, there is a very high level of interacquaintance familiarity among this elite milieu. The participants knew each other, or could very quickly locate one another in their social world. Consequently, the examples cited in this paper 
omit information about circumstances and places that accompanied the collection of data and all names are fictive, in order to preserve the anonymity of my participants.

\section{THE WORLD OF SOLOISTS: PLAYING AND WORKING TOGETHER}

Informal support networks structure the activities of this art world and organize around soloist teachers, who are the heads of their classes (Wagner, 2004). This microuniverse has a unique professional culture. According to Becker (1982), the professional culture of musicians' art worlds are specific, not only because of the knowledge of a particular interpretation and playing technique, but also because of the ability to collaborate with other categories of participants. Acquisition of this cultural capital and the process of becoming a soloist appear to be a long-term development. Most young musicians need about 20 years to complete their professional education and acquire the values and meanings of the larger social group to which they belong (Rose, 1962; Lindesmith, Strauss, \& Denzin, 1975 in Konecki, 1989, p. 65).

Led and organized by a master teacher, the soloists' class is the keystone of the student's musical education. Each teacher cooperates with the parents of young students in order to create specific conditions for the soloist's education and transmit their knowledge of the instrument and music culture through oral communication during individual lessons. Only those who know well the mores and folkways of this art world are able to enter into the closely-knit world of soloists. Socialization of soloists therefore consists of learning a specific lifestyle that focuses on violin practice and artistic personality. In the process, the young soloist student learns the role of the adult soloist and mentor.

Soloist classes take on the principal teacher's name, whose reputation guarantees the perceived quality and reputation of the elite's education. Adult participants of a soloist's world often use the term "stable of X" (the name of the teacher) to refer to the group of students under the tutelage of a particular master teacher. In Europe and in the USA, the reputation of the teachers ${ }^{2}$ and the development of their former students' careers influences the reputation of the major music schools (e.g., the Tchaikovsky Conservatory in Moscow; the Universities of Music in Vienna, Berlin, Zurich, and Karlsruhe in Europe; Julliard School in New York City; the 
Department of Music at Bloomington University in Indianapolis; and Curtis Institute in Philadelphia). Recognition, through the prestige of career pairs similar to other artistic (Heinich, 2005) or intellectual worlds (Ziman, 1987), determines and establishes one's professional position.

The soloist's education is a long journey during which students may undergo various types of selections (implemented by different professionals), which would potentially eliminate them from competing for soloist status. Therefore, many who begin the career-coupling process never achieve their goal. Engaging in such highly intensive musical education would be impossible for child soloists without family who supports and participates in the culture of music education. Thus, it is not surprising that the social background of my European sample is homogenous. Over 90 percent of students have a father or mother who is a musician (Wagner, 2006a). Below, I address the following question: How do young children transform into virtuosos, how do the "chains of cooperation" (Becker, 1982) work during the period of education, and how do participants pursue their careers within this world?

In the section below, I explain three stages in the career coupling of violin soloists: matching, collaboration, and cooperation, which can vary in duration for five or more years. The most intensive collaboration occurs in the second stage, when the optimal transfer of knowledge between mentor and young musician allows a high level of intensive work. This period is frequently characterized by a mixing of private and professional lives. The last stage does not require such intensive collaboration, but the names and reputations of the collaborators remain linked indefinitely. I describe these three stages in detail in subsequent sections.

\section{MATCHING}

The first stage of career coupling - the matching process - consists of selecting collaborators, which engage three categories of participants: the teacher, the student, and the parents. In artistic worlds, the previous reputation of the participants plays an important role in this process (Faulkner, 1983; Zuckerman, Kim, Ukanwa, \& von Rittman, 2003). A new candidate coming from a famous soloist master and soloist class has a better chance of successfully finding a match than an unknown candidate due to the fact that his/her former teacher was well known. The teachers evaluate candidates for their classes by considering the pupil's former teacher. The students, teachers and parents frequently express some version of the 
following opinion: good teachers know how to select the best students. According to this logic, to optimize the results of cooperation, the reputation (as well as the skills) of the two categories of collaborators must be similar. Hence, matching is a decisive factor in the process of career coupling, in which the expectations of the participants must correspond. A 17-year-old violinist after one year of collaboration with a new teacher stated:

You know, it is great with my professor. It is not like the other three before him. This one works with me completely. He does not change my arm position. Thus, I do not lose time. He says that if I play a certain way and it sounds wonderful, I can continue! Unlike my previous teachers who told me $I$ needed to play a certain way or put my elbow higher. Not only that, but we also have the same feeling about the style and interpretation of pieces. The lessons are not stressful. They are a part of the pleasure.

Despite the need for matching, the teacher must be convinced that the student corresponds to his/her expectations. Each person has his/her own criteria of excellence in playing and demeanor. The subjective perception of a virtuoso's performance constitutes the most important factor in the choice of a partner for career coupling, which can be difficult given different needs from the relationship. If the two parties are not satisfied, because, for instance, the master is perceived to be too strict, but the disciple expects some independence, they may break their collaboration. Parents often play a central role in mediating these collaborative relationships by preparing their children at home and supporting their budding careers through active involvement in the coupling relationship.

\section{The Role of Parents}

In order to establish good communication between teacher and student, the parents act as the teacher's assistants during lessons. At home, they help with daily instrumental practices. As my observations suggest, the degree of parental immersion within the soloist's world heavily influences the interaction between the teacher and the parents.

For children who originate from nonmusical families, the teacher performs the primary process of socialization within the soloist world. The teacher introduces not only the child, but also the novice parents into this professional world. This can be a very difficult situation to socialize both student and parent due to differences in cultural capital, musical knowledge, or familiarity with the social world of musicians. Even if a collaborative relationship emerges, it frequently collapses under its own weight. For this 
reason, it is uncommon for children of nonmusician-parents to go through all steps of soloist education. If nonmusician-parents do not share the value of music expected in the soloist world, such as the priority accorded to violin practice over general schooling, continuing the soloist's preparation is easier with musician-parents who value its centrality in the child's development. In such a case, the parents and the teacher share the initiator role. Instead of having one parental authority, the soloist child now has two: the parents and the teacher. The soloist teacher establishes the life project for the child, and the parents must adhere to his/her decisions and advice for the collaboration to succeed. This is why the first objective of a teacher is to establish good collaboration with the student's parents to provide the quickest possible progress of instrumental education.

The following statement made by a Russian teacher is common: "I do not need prodigy students, but gifted mothers." It illustrates the key position of parents at the first part of soloist education (between the teacher and their child), in order to create a clear path of communication between them. The parents often take the role of translating the teacher's expectations, and explain to their child what the teacher's words mean. One soloist, age 30 , described the role of her mother-pianist in the soloist's education:

\footnotetext{
My mum accompanied me in my first years of learning. She explained everything to me: because my teacher did not have the time or patience to explain it in "little girl's words," but mom patiently explained all that he said after the lesson. She was the one who said it was very good, because my teacher simply said, "OK" and that was it! For him, the program that I played was the best reward for my work, and the best proof of my violin skill progress; however, for me, this was insufficient. I did not understand that! Soloist teachers are busy, and in most cases, seen as "racing for time."
}

The perceived "busyness" of the soloist teacher spilled over into general expectations of a child's progress through the musical program. Therefore, the child must accomplish the program very quickly to preserve his/her place and status of "precocious child" or "prodigy." Additionally, the parents must take time between lessons to explain and complete the master's teaching and coaching. On one hand, the parents explain to the child the teacher's remarks and orders. On the other hand, they educate their child to adopt the behavior to conform to the teacher's expectations (because the musician-parents know these expectations very well). These parents struggle for a special teacher's care and attention for their child. Knowing the importance of a career-coupling relationship they make severat efforts to show their child capable to be a "soloist."

In the soloist's class, the parent prepares the child before he/she enters the lesson. Consider the following example of a mother speaking to her 
seven-year-old daughter in the corridor of the music school before she enters the classroom. "You must be focused and you must react very quickly. You know that the best violinists have a big temperament, so do not act like you do at school. Do not fall asleep. Please, be good, but like at home-full of energy!" This mother, a pianist, who was also a soloist student and well aware of the proper presentation of self, prepared her daughter to demonstrate her "artistic personality." Like the interview suggests, she is convinced that the soloist teacher would invest in the work only if he estimates her daughter as somebody with talent, and the "potential to become a soloist", an expression used by numerous teachers of soloist classes.

What do teachers and musician-parents understand by artistic personality? Some of them consider that an "artistic personality" describes a child with an extroverted temperament, who works quickly, who has "one hundred ideas per second," is interested in various subjects, and is "good in mathematics and chess." Participants from the soloist world also share this image of "artistic personality." It belongs to the cultural knowledge that parents transmit to their child, by encouraging behaviors that conform to this image.

The notion of artistic personality plays an important role in the selection for career-coupling relationship, such as in the example of an audition for the well-known soloist class at Julliard. "DeLay hears about 250 auditions for Julliard each year, and has described that meeting as being akin to a first conversation, since it reveals not only performance ability, but also the crucial aspects of intelligence, humor, and personality" (Lourie-Sand, 2000, pp. 95-96). Parents focus on making their child look capable of becoming a soloist, not only in the aspect of their artistic personality, but also in other aspects perceived as specific features for soloist performers: good physical form and excellent health.

Parents can provide this information in other ways, as well. They inform the teacher about what the child has done at home, and about the emotional and physical health of the child. Usually, during the lesson, the rule of the soloist student is that he/she does not speak, which is why the parent must provide the teacher with a variety of information about the student. The child's role is to play, to take corrections and orders, and to answer questions about performance. In order to excuse a student's weak performance, I observed parents explaining to the teacher that their child was "ill" or "busy," rather than revealing that the child had simply "not practiced."

These explanations are not frequent, however, because a soloist simply cannot be ill or busy! $\mathrm{He} / \mathrm{she}$ must always be ready to play. One teacher said, "At 3:00 a.m., if you need to play, you must play the best you can. 
You know, seven-year-old [Maxim] Vengerov practiced at 1:00 a.m., because his parents couldn't work with him earlier!" 3 From a very early age, parents socialize the child with difficult conditions of playing at any hour, in various circumstances. The child most often listens to stories about other violinists - children who perform very well (in the opinion of their teachers) despite difficult conditions.

This last example leads us to a motivational technique, where teachers implement examples of "professional idols." Robert Faulkner (1983) described this phenomenon after analyzing the consequences of "professional idol" projections in an orchestra musician's life. For violinists, this connects with the "awakening" of a strong, professional ambition, which is essential to support the efforts of all participants responsible for transforming a young student into a professional.

The parents confirm the educational path imposed by the teacher. I have observed many families who, according to the teacher's expectations, organize the student's life as follows: Students participate in the master's class. They take part in competitions. They study in the soloist summer class and at a special general school for musicians. The child meets with the teacher several times a week. Each day, when in the master class or another class, there is a competition for which to prepare. Consequently, the teacher grows closer to the student's family, and has a strong influence on the nonmusical education of the student. The following example of a teacher speaking to his student's mother illustrates this point:

You know, I have taken care of your son for more than three years. I have spent a lot of time with him, and I have invested a lot of time in his education. OK, it's musical education, but you know, I think that I can intervene in other areas of his education. For example, he needs to visit museums, to read literature, you know, not only play the violin. I mean that I have the right to impose that on him. In a sense, I'm a part of your family!

At this point in such a relationship, the boundary between the private and professional relationship is blurred. This closeness with the teacher demonstrates to the child the appropriateness of mixing private relationships with professional ones. The emotional state of the relationship with the teacher surpasses that of the cold business of professional teaching. Here, the teachers impose the modes of education on their students. Consequently, the child in such a relationship adopts an important supplement to parental authority in his/her life. In turn, the observed child alters his/her behavior to this division of roles, knowing that the teacher is the most important person during soloist lessons. 
Though they provide the teacher with the space he needs to instruct, the parents always remain in the teacher's shadow, taking notes, recording on tape, or filming the lessons. The teacher speaks, and then plays. Then the child plays. Along with his/her family, lessons with the master are the most important element of the violinist-child's life at this stage - they "play" their future: "You know, all people here know that - if you put your child in very good hands very quickly in his life, he has the best chances to play in solo afterward, obviously, if the teacher wants to work with your child as it should be done." For working intensively with a given student the teacher has to see the potential in his/her student. The soloist education is a very long-term process in which each lesson is a confirmation, or not, of the "child's talent." If the lesson "is good," the teacher is pleased, and the family has achieved its objective. If the lesson turns bad, and the teacher is not satisfied, the whole family becomes frustrated. Yet, how do the teachers manage to cultivate this strong involvement in their occupational project?

\section{Ambition}

For those in the violin world, ambition is the strong desire that a young musician becomes a soloist. ${ }^{4}$ In this process, the ambition of a teacher has to coincide with the ambition of the parents and then the young musician has to share this desire. At the beginning of a young soloist's career, he/she encounters the parents' ambition through their proximity to this world as accompanists, violin players, violin or piano teachers, and sometimes, sound engineers. Famous American virtuoso, Ruggierro Ricci remarked, "believe me, when you find a prodigy, you find an ambitious parent in the background" (in Schwarz, 1983, p. 534). Despite this tacit ambition, it is not frequent to hear parents speak explicitly about their deep desires for their child's future. But their actions, such as personal investment in time (each day supervision), finance (payment important fees for lessons), and organization of family life (no sports, short holidays break, the life which is organized around intensive practice on violin), constitute the best indicators of their expectations about the career of their child.

During a competition for young violinist I had a long talk with the official competition accompanist who graduated from Tchaikowsky Conservatory in Moscow and emigrated to Italy; she was the mother of 18-month old and said, "You know, I will stay in Italy two years more but after I have to move to Berlin, because Vadim works there with his students. And with my experience you can be sure, that this is the best teacher for a young 
violinist." Before her child was able to play, she projected important changes in her family life (moving from Italy to Germany) in order to give him the possibility to be taught by the "best teacher."

According to Becker, Strauss, and Carper (1956), parents often aspire for their child to have an elite career in their particular occupational field. Musician-parents, therefore, hope that their child will become a member of the elite as a soloist. This strong parental ambition must interact with the teacher's ambition. Several times I could hear from these teachers how their students performed "better than other violinists" during a competition. The sentence such as "he will be well known very soon" or "you will hear about her frequently" accompanied violin lessons when the discussion was about the "best students" of this teacher. One of them called such students "stars students" and at each technical explanation, she used the example of one of her four star students and explained how quickly she resolved a problem in and how excellent her performance is now. Masters need excellent students, because through them, they are able to show the product of their work. Within their circle, violin soloists frequently express, "Masters play through their pupils." Additionally, when the master feels that the child has the potential to become a soloist, lessons begin with a strong desire that the student will become one.

The master's ambition, therefore, facilitates active involvement in the child's musical education. To accomplish this, the teacher often provides free lessons, organizes concert performances, prepares the student for competition, lends them a violin free of charge, and mobilizes the student's entire support network to collaborate. The teacher, as an expert, coach, head of the network, and influential professional, is a powerful person. ${ }^{5}$ It is worth noting that the teacher does not provide such level of attention or do favors for all of his/her students, which is why the parents struggle to obtain the best position for their child in the soloist's class. Only those students, who the teacher deems as having great soloist potential, benefit from such special treatment. This special treatment meets strong criticism from parents and others who do not have their own children involved in such rigorous training and do not share the same desire for "virtuoso production." During an interview, one violinmaker explained this phenomenon:

What can I tell you about a violinist's education? I have observed them for more than twenty years now. Each day they come into my workshop, and I can only say one thing: it is crazy stuff, this system, and has nothing to do with music. This is a factory that creates so-called "musicians" anc all that is born out of this is crazy parental ambition. They are sick, all sick of this incurable illness - known as ambition. 
The last person who becomes involved in this "ambition chain" is the young player. After the parents and the teacher share a common soloist ambition for the child, they intentionally try to awake a similar ambition in the child. The very young children I have observed like to play on stage, and enjoy the applause of their adult public. They say frequently that they "like to perform," "like to play," and "they aspire to play like (a particular professional violinist)." Despite the fact that public performances are a source of satisfaction for them, the tedious daily instrumental practice is often perceived as a problem for the young soloist.

\section{When Music is Hard Work}

The progress of a musician depends on the practice (at home) between two lessons. In the first part of the soloist's education, it is a major problem for students, because even if the parents and teacher share a common desire for the child to practice violin often, intensively, and for long hours, the young virtuoso is not always as enthusiastic about such hard work. ${ }^{6}$ I observed several examples of passive or active resistance to hard work. When children practice without direct supervision, they could play in their room simultaneously looking at TV or reading a book or playing another piece of work than ordered by teacher. Students may also simulate illness, muscle fatigue, or broken strings. One particular student broke her violin twice, simulating an accident to prevent her from practicing at such a demanding level. In fact, all interviewers said that they had difficulties practicing the number of hours imposed by teachers and many develop strategies for cheating. ${ }^{7}$ Indeed, the teachers recommend the time of daily practice, depending on the age of a pupil: from three to five years old, one hour and a half; more than 6 years old, 2 hours, and 7/8 years old, minimum 3 hours, and then quickly achieving 4, better 5, hours (excluding the periods of break).

In light of this intense effort, which teachers require from their students, ambition is often the motivating factor for hard work. The students and their parents do not receive immediate rewards for the instrumental practice, and must work intensively for several years in order to attain the high level necessary to play the soloist's repertoire. Gratification comes from the recognition of the precocity and potential of the young soloist when, for example, he/she is able to play a difficult piece like Paganini's fifth Caprice before the age of 10 . Acquiring such a repertoire means that the player has great soloist potential. Again, the parents, following the teacher, transmit to 
their child the key to understanding the significance of this gratification. This collaboration with musician-parents, however, may not always create fruitful results, even if the ambitions of both parties are similar.

As in all situations of interaction, being from the same professional world does not protect parent-violinists (and other instrumentalists) or the teacher from conflicts about the precise strategy of the career, such as program choice, concert preparation, choice of competition, or even the technical aspects of violin practice. Because of these conflicts, I observed children who never took more than one month of lessons with the same teacher, because the parents held a "no-one-is-good-enough" attitude. The lack of peaceful and long-lasting collaboration between this triad constitutes a huge obstacle when pursuing the soloist education; it is the common motivator to abandon the project of becoming a soloist altogether.

\section{Mutual Dependencies}

The relationship between the participants at the matching stage of soloist education is of a specific nature: the teacher gives time and knowledge to the students, whom he/she evaluates as promising, in exchange for money, or sometimes some parental service. I observed one teacher who said to his student after a free lesson, "You know, my master, Yankelevich, says frequently, 'I have two categories of students: the ones who pay for lessons and the others who are gifted." When the teacher gives free lessons, the participants in the soloist's world perceive that as recognition of the student's potential, and the most important compensation for the student's hard work.

When the teacher decides that the young soloist has achieved the level of playing appropriate to participate in competitions, he/she prepares the student for this important performance. In doing so, the teacher shows the student to other soloist teachers and, through his/her student's performance, the master builds his/her own reputation. The students who participate in these competitions become a business card of sorts for their professors. Barbara Lourie-Sand, in the biography of Dorothy DeLay, writes, "Teachers owe their reputations to their successful students and even the greatest pedagogues are usually known only within the music world" (Lourie-Sand, 2000, p. 41). The case of Eastern Europe violin teachers who emigrated in the 1990s best illustrates such dependency; a majority of students are in a migrating situation frequently because they follow their teacher to maintain the mentoring relationship. In order to pursue their 
work with their best students, the teachers struggled to take them to Europe or the USA. Without these "imported star students," the teachers' careers would have easily collapsed. The other option for these immigrant teachers was to stay behind and rebuild a new class of soloists. By doing so, they would have lost their earlier reputation, thus reverting to a previous stage in their careers.

Young performers not only build their teachers' reputation, but also their own, constituting the basis of the soloist student's career. This is a crucial moment for the career of teachers and their students. Competitions are an opportunity for a young soloist to earn a place in their soloist world. During these violin competitions, the all-important participants of a young soloist's world are present: famous teachers (in the role of members of the jury), potential future soloists, accompanists, agents (at times), sometime conductors, and frequently parents.

Participation in competitions from an early age is specific to the soloist class. It is a good opportunity for teachers to maintain the relationships with the participants of the soloist world, either alone or through their student(s). The teacher indicates what a student has to do, and how he/she can take part in such relationship building during competition. The teachers do not hide that the quality of performance at competitions is not the only means of deciding who the "best" violinists are (Wagner, 2006a) ${ }^{8}$ Beginning from the first competition, young participants learn that a very good performance constitutes only one part of the evaluation criteria. The name of the teacher is also important. They learn that in order to win, it is most important to be close to a teacher who holds some degree of power in the professional world. This mechanism also explains why it is so important for teachers to belong to a jury in their career. It is not only an opportunity to show that they are important, but also the possibility to push their students forward. After the period of matching, when the two categories of participants are satisfied, the phase of active collaboration begins.

\section{ACTIVE COLLABORATION}

In order to create favorable conditions for collaboration, the two participants spend a lot of time working together, including outside the workplace. Playing chess, sharing meals during festivals, competitions, concerts, etc. give them time to develop the relationship. Sometimes, a professor can provide accommodation for his student - a behavior quite common among Eastern European musicians who emigrated in the twentieth century. 
A famous example is Galamian's flat in Manhattan (See Schwarz, 1983, pp. 547-550) in which several students lived and work in during the months and years. Again, we have the case of strong proximity, which provides the ability to mix the private and professional relationships.

Coupling partners, thanks to their proximity, influence the work dynamics and this is crucial to the stimulation of results. The master stimulates students to practice more and play better and the student stimulates the master to devote more time to them, to organize for him the concerts; the participation in TV programs, to invite critics to performances, and to negotiate the contracts with agents and to invite the conductors to play with this student. Because the teacher has more students, and careercoupling relationships take up a lot of time by working with only one student, this kind of strong attachment is possible only with a few students at the same time. The young virtuosos know that, and that is why they search to have as close a relationship as possible with the master. Having such intimate access to the teacher means more free lessons and other supporting aforementioned actions. However, this strong relationship is not only a period of intensive and passionate work, but also a period of constant negotiations between the participants, whose perception of this relationship is sometimes unclear, as a 19-year-old violin student suggests:

She (the teacher) rather wants to be my mother. Yes, I think that it embarrasses me. I do not want her to know where I am at midnight. I hope that she understands this now; but this is natural because she wants me to work very hard. I can only be grateful to her. This is why I say that she is at the same time a tyrant, and that is normal. In addition, she works with me a lot, and I do not pay for all this time, because she says that I am her means of showing her knowledge. Also, we are tied together; we have a common interest, and that is all.

During the stage of active collaboration, each participant constructs his/her career using the partner's knowledge or abilities in coupling. Knowledge from the initiator enriches the novice, and the initiator profits from the performances of his/her young follower. The teachers show their art through the performance of students, principally through participating in competitions.

\section{Construction of Reputation}

Through participating in competitions and other public performances, niaster and disciple build their careers together, and their world quickly knows about their coupling. When a violinist plays, other violinists recognize 
the details of interpretation and style of performance, which are the results of a teacher's work. These not only include coaching and psychological preparation, but also this professional "touch," very smart finger organization, beautiful strokes of the bow, and a recognizable sound. The violinist plays and the professional public judge both the student and the teacher's art. "The hand of a master" is visible (or audible) to professionals, who quickly recognize the teaching style. Because the violin soloists' world is so small, people know one another personally or through their production: CDs, news from competitions, and/or TV programs, and recently through the Internet.

In this world, information about artists, their work level, and improvement spreads rapidly, and this knowledge about the people is the basis for their reputation. In the worlds where the process of career-coupling builds careers, following rules where only the best musicians work with the best, we can consider that Merton's "Matthew Effect" (Merton, 1996. pp. 318-323) whereby "the rich get richer and the poor get poorer" applies to both partners. Because the artists build their reputation in reciprocity, the social and cultural capital of one partner influences the relative success of the other.

In addition, the world comes to recognize an unknown participant through a well-known career partner. It is why the first question to an unknown virtuoso is: "Who is your master?" The extension of reputation is a consequence of coupling, which means that it does not always have a positive effect. The participants are attentive to the reputation of their coupling partner, as the following example suggests.

The conductor of a German orchestra advises a young 20-year-old virtuoso on her project of intensive collaboration with one teacher, who works with the student from time to time:

You must be careful, because it is dangerous to join his class. He does not have a very good reputation in Germany, and you will have difficulties playing in concerts after being in his class. Perhaps you will only win these competitions when he is in the jury, and that is all. Think about this before you join his class.

However, the participants' reputations are changeable and the risk of "losing a good reputation" exists. Such a situation occurred to a famous teacher, whose student stopped winning competitions. This student did not achieve the same level as those in the middle of his career. When one collaborator loses his/her good reputation, the coupling partner must save his/her own (reputation), cut the coupling process, and communicate this to others within the soloist world. 
This was the case of a young violinist from England, between the age of 11 and 15, who was educated in the class of a famous teacher in Germany. When the teacher began to lose his good reputation, she changed teachers and worked with a debutante teacher, a famous soloist herself. She did not mention her old teacher, even though it was through them that she achieved her status as a virtuoso player. The new teacher worked with her for approximately one year only, which was not sufficient to create a soloist. Nevertheless, the young soloist would not be associated with the old teacher who held a bad reputation. She cut the process of career coupling and made a new relationship with a virtuoso who had a good one. Moreover, the soloist world recognized quickly that she changed her career-coupling partner. However, the end of active collaboration of the career-coupling stage is rarely the result of conflict.

Most often, the student makes the move for more distance because he/she wants people to evaluate him/her independently from the master. When the world of soloists has recognized the link between the partners of career coupling, and they have acquired professional skill and knowledge, then the activities of both individuals are less dependent on each other than in the stage of active collaboration.

\section{The Emancipated Student}

During this second phase of development, the majority of students do not need the assistance of their parents at every lesson, because they are able to practice on their own, thus changing the relationship between mentor, mentee, and parent. The child, who once was obedient and submissive, starts to claim the right to become an equal partner: he/she has a growing desire to choose the repertoire, the music interpretation, the competitions to prepare, and the master class to join. Emancipation from parents and modification of the relationship with the teacher takes place simultaneously, cementing the growing importance of these relationships with the soloist's classmates. With them, they exchange all necessary information and share feelings about their common experience of a soloist student's life.

In the matching phase of a soloist's education, parents and teachers are used to putting the young performers in the position of a competitor. In the collaborative phase, they learn together how to maintain partnership relations. They create new ties in place of old ones: the parents and teachers do not influence their protége in the same ways they did previously. In this period, students often change teachers when they do not accept that their 
disciples are no longer submissive enough. Consequently, the students move from one network to another, because every soloist teacher builds his/her own network (Wagner, 2004). The process of changing teachers is extremely difficult, and there is always a sense that the process delays a certain level of progress in the student's career. The teachers hope that this time of instability will not last very long, and will not affect playing and collaboration. At this point of their education, young soloists confirm or deny the professional decisions made by their parents as to whether they are going to become soloists. It is not surprising if we consider the age of soloist at that period, as many adolescents would like to make decisions about their future independently. The young soloist must continue to share the parent and teacher's ambitions about his/her career. As one 20-year-old violinist said:

Each person decides if he or she wants to become a violinist, because in the beginning, the parents are the ones who tell you to work; but in time, they will no longer be there, and the student will have to do it on his/her own. We work alone with our violin, and we have the desire to play or we do not. That is all. Those who do not want to do it, leave! It is not true that we feel obligated. The small child, yes, but not later.

Some students decide to stop their education as a soloist and change their professional objectives. While many explain that it is because of the lack of success in their solo career, I could observe some exceptions. One student, in particular, who, after a very successful career as a prodigious child, changed her objectives and decided to become a physician by enrolling in a medical school. Those who carry the parental and teacher's ambition on their shoulders and pursue the objective of becoming a soloist look for improvements in their playing technique. The majority of them think that their own performance is too far away from their ideal model of a "soloist performance." Living up to these high standards, the students practice more intensively, but are often less enthusiastic about their public performances and express serious doubts about their future as a soloist.

As Schwarz reports in his study concerning the greatest violinists of the twentieth century, numerous virtuosos broke off their concert activity during adolescence (Schwarz, 1983). It was difficult for them when they no longer benefited from the earlier tolerance of their public as being a young soloist in "shorts," especially if they were prodigies in their childhood. 9 An 18-year-old violinist, who was once a prodigy, explains:

When I dropped my first professor, I was fifteen. It took six months to correct my posture (a technical term meaning the manner of taking an instrument and playing), and after that a few months for getting better psychologically. The last two years were very difficult for me. I had stage fright many times! I, who never had stage fright before-even 
in front of the most important audience - had this impression of becoming nobody, an impression of knowing nothing, not even notes! An impression of going backwards. I wanted to stop playing several times, and I went for two-months without touching the violin! Happily, this is the past, but I still feel fragile, and I have difficulties with playing before an audience, which I never used to have.

After a period of hesitation, the students are convinced that they need a teacher, but they want relationships other than those characterized in the first part of their education. Young musicians now have the authority to decide what they hope to learn from their teacher. If they estimate that the current teacher does not give them what they need, they promptly change teachers. They do not believe, as in the past, that their master is perfect and unique. Because they now know the career pattern in their professional world taught by soloist teachers, their musician-parents, and soloist friends, they look for a strong collaboration with a teacher who can push them into the highest stages of the soloist market. After the first part of soloist education, they understand all the obvious rules in this world. Once this period is over, they come to realize that this close teacher-student relationship is one of the key elements of their future. They recognize how their career is coupled to their mentor's career.

\section{COOPERATION: COMPLETING CAREER COUPLING}

This final, cooperative stage of the coupled career corresponds to the introduction of a young professional into the labor market of adult musicians. In the meantime, the participants pair both names (teacher and disciple) to aid in the furthering in their respective careers. Young soloists maintain this relationship (which they previously learned to create and maintain), making sure to mention their teachers in their personal biographies printed in concert programs. Teachers do the same by including the names of former students in publications and elsewhere in the media. The 80th birthday of DeLay is a good example of the activity of maintaining ties that bind this powerful teacher with her former students. All her star students were present at the party.

Additionally, if a former student reaches a successful recording or performance, and the press mentions this event, the teacher comments on that fact, providing more information about the successful soloist, further explaining the depth of the relationship they have with that given student. As in the artistic world, peer recognition determines the careers in the professional world. Consequently, the coupling of participants constantly 
builds reputation. Within the passive collaboration stage, each person is evaluated independently; but the development of the ex-partner's career continues to influence the reputation of the partner (now ex-partner) in career coupling.

Furthermore, not all students who were taught by a famous teacher developed this career-coupling relationship. There is a distinct difference between being "a student of a famous master" versus simply being "his or her student." As a former student from the Tchaikovsky Conservatory told me, "Yankelewitch had hundreds of students when he was well-known; but his esteemed soloists students were only those who took lessons with him for years, day by day." I heard a similar statement from a student regarding Doroty DeLay and her own privileged students.

Participants perceive the haphazardness of a positive interaction between careers, in the form of career coupling, as the source of failure in occupational routes. To achieve recognition of the career-coupling relationship, the partners must go through the three stages of coupling analyzed in this article. Other persons who collaborate with them, who we do not consider the participants involved in the career-coupling process, are simply supporters. Even if this relationship is crucial for the successful career in the elite soloist's world, other contributions in several categories of people (conductors, violin makers, agents, sponsors) are also important in the course of their professional life (Wagner, 2004, 2006a).

\section{CONCLUSION}

Career coupling is the social process concerning the professional and parallel routes of two or more participants who cooperate - each one with a specialty - during a period long enough for them to change at least one of their professional positions. Through this process, the individuals hope to achieve professional success. Coupling means that the partners who are involved in this process build their careers together. I have demonstrated in this article that the effect of both partners in career coupling is mutual. I demonstrated how parents prepare their children to create and maintain career-coupled relationships. Socialized from early childhood, young musicians recognize the importance of future career coupling with an excellent and famous teacher.

My analysis of career-coupling processes shows that this relationship is one of mutual dependence and strong collaboration. In light of the interactional character of this phenomenon, it is very difficult to develop a 
strict typology of the "successful teacher" or "successful student." This is because career coupling is an interactional, dynamic process, which takes place in a specific, equally dynamic context. Instead, it is more appropriate to examine those configurations that lead to success or failure. In addition to this process, there are several factors, temporarily determinate, which are indispensable for a successful education. The young musician needs to pass several selections during socialization. Each selection is different (provided by a different category of professionals depending on various criteria, which could be opposite from one selection to another), and could potentially be definitive, and responsible for failure (Wagner, 2006a). The soloist education is a long road, based on the collaborations between different categories of people. Among those collaborations, the career-coupling process constitutes the most important.

We can observe similar mixing practices in other professional worlds (Wagner, 2006b). But what is more common in the professional worlds of soloists is the professional socialization of children. The art of (creating and maintaining) private-professional relationships constitutes the basic part of the socialization of young soloists. As I have shown in this article, professional socialization transpires in concert with family education. As a result, the musicians reach the primary and secondary socializations (Berger \& Luckmann, 1966) during the same period, which is an exceptional phenomenon, because the majority of contemporary occidental societies separate family education from professional socialization. Usually, the former is transmitted in childhood before the latter. Parents and teachers begin this accelerated and intensive socialization from the first violin lesson. When the student acquires "savoir faire" in the matter of those relationships, he/she can construct a career according to the rules of the soloist world. The teachers and students construct their reputations together. They are interdependent. However, career coupling likely occurs with collaborators who share a similar status.

This analysis suggests that career coupling and the support network constitute a social process employed by professional groups for maintaining social control, especially through the acceptance of newcomers into their milieu, and constantly evaluating the elite members' work. In the adult careers of performers, virtuosos connect their career with those of other participants: conductors, pianists, or concert organizers.

Participants cooperate with each other because they believe that their collaboration will let them approach what they perceive to be professional success. Despite the fact that I base this concept on the study of soloists (which is perceived as a special, sometimes even as a marginal world), 
I argue that this phenomenon is widespread in other occupational and professional worlds, such as those between coach-athlete, doctor-nurse, executive-assistant, and even sociologist-sociologist (Wagner, 2009). Elsewhere, I have carried out this research and have observed and analyzed the career-coupling phenomenon in the world of scientist-laboratory researchers (Wagner, 2006b).

This mechanism is particularly clear in the case of elite production, especially in the professional circles where the careers are based on peer reputation, rare and highly specialized expertise and informal transmission of knowledge. This specific interactional model is characteristic of professionals working in other artistic specialties or as high-profile chefs, Olympic athletes, and life-science researchers (Wagner, 2009, 2010a, 2010b) and therefore could be used to analyze other paths in the "production of excellence" process. In previous work, I showed how this specific relationship influenced the careers of important sociologists, such as Bourdieu and Merton (Wagner, 2009), and how some of their collaborators suffered from the negative effects of this process. I also presented this concept as a pedagogical tool - career coupling could be a helpful concept in teaching classes of theory as well as a history of sociology.

This paper begins to conceptualize processes of career coupling. This analysis of the interactive process of career coupling is designed to contribute to a better comprehension of the functioning and socialization processes of various professional worlds. These results and theoretical proposition should help us in the understanding of the social activity, relationships, and interactions that are part of the music profession. The career-coupling theory is potentially applicable to other professional social settings and practices such as the world of the elite scientist and many other social worlds.

\section{NOTES}

1. In addition to my qualitative sample of 90 violinists, I brought in additional participants from six international violin competitions between 1995 and 2002 in the EU, creating a statistical sample to include 339 students. I supplemented this data with biographical books about performers from the violin world and with the musicians' press. Furthermore, I have accumulated documentation about the activity of 40 violin teachers.

2. The teachers of soloists with a good reputation are really few. For example, in the USA in 1945-1990, according to Schwartz (1983), there were only four teachers. Sherwin Rosen (1981) considered that: "The market for classical music has never 
been larger than it is now, yet the number of full-time soloists on any given instrument is also on the order of only a few hundred (and much smaller for instruments other than voice, violin and piano)" (Rosen, 1981, p. 847).

3. That information was provided from the biographical TV program devoted to Maxim Vengerov. This program was the subject of several discussions in the young virtuosos' world - the "authenticity" of the presentation of Vengerov's life was discussed (it could be compared with Lavigne's authenticity perception analyzed by Vanini, 2004, 2007).

4. Professional ambition concerns not only artists. As Hermanowicz (1998, p. XIII) suggested in his study of the careers of researchers in physics: "The scientist, like the artist or the athlete, follows a pantheon of immortal figures who have achieved a place in history through exemplary performance. The achievements of these figures set a competitive standard for all those who embark on a given professional path. Who aspires to be a mediocre Johnny Unitas, a second-rate Beethoven, or a watered-down Newton? A desire for greatness - an imagined possibility of what one becomes ignites a career and often sustains it."

5. The presentation of American master of violin Dorothy DeLay gives us a worthwhile illustration of the power a teacher can have: "DeLay is hardly just a nice lady who teaches the fiddle. For more than half a century, she has been a power-behind-the-throne, unknown outside the classical music world, but a legend within it" (Lourie-Sand, 2000, p. 16).

6. In my forthcoming book Producing Excellence - Social Production of Virtuosos, I analyzed this very interesting phenomenon of child resistance using Donald Roy's work.

7. Jalagin, a famous student of the most famous soloists' class reported that his master: "Stolyarsky demanded that his pupils took the violin out of the case immediately after breakfast and put it away just before they went to- sleep at night. ... All other activities, including general education, were expected to be cut to a minimum. The child's entire life had to be devoted to the violin" (Schwartz, 1983).

8. We can note here, that for six competitions observed, the finalists were always the students (from a class of soloists or a master class) from members of the jury.

9. In this paper I do not focus on "prodigy children" topic, but there is a very heavy tendency of favoritism toward precocity. This phenomenon enhances the acceleration of careers - see M. Villette (1975).

\section{ACKNOWLEDGMENT}

I would like to thank the reviewers and SSI editors, especially Robert Gardner, for their precious advice and strong support of my research. Their patience and understanding of a non-English native speaker sociologist were exemplary. I am also very grateful for the support and suggestions of Bob Faulkner and Bob Prus, who always were very enthusiastic about my research. 


\section{REFERENCES}

Adler, P. A., \& Adler, P. (1991). Backboards \& blackboards. College athletes and role engulfment. New York: Columbia University Press.

Adler, P. A., \& Adler, P. (2005). The identity career of the graduate student: Professional socialization to academic sociology. The American Sociologist, 6(2), 11-27.

Becker, H. S. (1970). Sociological work. Method and substance. Chicago: Aldine.

Becker, H. S. (1982). Art worlds. Berkeley, CA: University of California Press.

Becker, H. S., \& Strauss, A. L. (1956). Careers, personality, and adult socialisation. The American Journal of Sociology, 62(3), 253-263.

Becker, H. S., Strauss, A. L., \& Carper, J. W. (1956). The development of identification with an occupation. American Journal of Sociology, 61, 289-298.

Berger, P. L., \& Luckmann, T. (1966). The social construction of reality: A treatise it's the sociology of knowledge. Garden Cuty, NY: Anchor Books.

Burawoy, M. (2005). Combat in dissertation role. The American Sociologist, 36(2), 43-56.

Campbell, R. A. (2003). Preparing the next generation of scientists: The social process of managing students. Social Studies of Science, 33(6), 897-927.

Duneier, M. (2007). On the legacy of Elliot Liebow and Carol Stack: Context-driven fieldwork and the need for continuous ethnography. Focus, 25(1), Spring-Summer. Available at http://www.irp.wisc.edu/publications/focus/pdfs/foc25le.pdf. Retrieved on August 2009.

Faulkner, R. (1983). Music on demand. New Brunswick, NJ: N.J. Transaction.

Ferrales, G., \& Fine, G. (2005). Sociology as vocation: Reputations and group cultures in graduate school. The American Sociologist, 36(2), 57-75.

Heinich, N. (2005). L'elite artiste. Excellence et singularite en regime democratique. Paris: Gallimard.

Hermanowicz, J. C. (1998). The stars are not enough. Scientists - their passions and professions. Chicago: The University Chicago Press.

Hughes, E. C. (1971). The sociological eye: Selected papers, Everett C. Hughes. Chicago: AldineAtherton.

Konecki, T. K. (1989). The methodology of the grounded theory in the research of the situation of work. The Polish Sociological Bulletin, 2, 59-74.

Lindesmith, A., Strauss, A., \& Denzin, N. (1975). Social psychology. Hinsdale, Illinois: The Dryden Press.

Lourie-Sand, B. (2000). Teaching genius - Dorothy delay and the making of a musician. Portland: Amadeus Press.

Merton, R. (1996). On social structure of science. Chicago: University of Chicago Press.

Reskin, B. F. (1979). Academic sponsorship and scientists' career. Sociology of Education, 52, $129-146$.

Rose, A. M. (1962). A systematic summary of symbolic interaction theory. In: A. M. Rose (Ed.), Human behavior and social processes. Boston, MA: Houhgton Mifflin.

Rosen, S. (1981). The economics of superstars. The American Economic Review, 71(5), 845-857.

Schnaiberg, A. (2005). Mentoring graduate students: Going beyond the formal role structure. The American Sociologist, 36(2), 28-42.

Schwarz, B. (1983). Great masters of the violin. New York: Simon \& Schuster.

Shulman, D., \& Silver, I. (2003). The business of becoming the professional sociologist: Unpacking the informal training of graduate school. The American Sociologist, 34(3), 56-72. 
Traweek, S. (1988). Beamtimes and lifetimes: The world of high energy physicists. Cambridge: Harvard University Press.

Vanini, P. (2004). The meanings of a star: Interpreting music fans' reviews. Symbolic Interaction (Winter), 27.

Vanini, P. (2007). The changing meanings of authenticity: An interpretative biography of professors' work experiences: Studies in Symbolic Interaction, 29, 63-90.

Villette, M. (1975). L'accès aux positions dominantes dans l'entreprise. Actes de la recherche en sciences sociales, 1(4), 98-101.

Wagner, I. (2004). Les liens et les réseaux dans la formation de virtuoses. Sociétés Contemporaines, 56, 133-163. Paris: l'Harmattan.

Wagner, I. (2006a). La production sociale des violonistes virtuoses. Doctoral thesis, EHESS, Paris.

Wagner, I. (2006b). Career coupling: Career making in the elite world of musicians and scientists. Qualitative Sociology Review, 2(3), 2. Available at: http://www.qualitativesociologyreview. org/ENG/archive_eng.php. Retrieved on July 2009.

Wagner, I. (2009). Coupling career fairy tale "Fascinating Sociology Class." How to teach sociology? The sociology of sociology. Qualitative Sociology Review. Available at: http:// www.qualitativesociologyreview.org/ENG/Volume14/QSR_5_3_Wagner.pdf. Reviewed on March 7, 2010.

Wagner, I. (2010a). Kariery $i$ mobilnosc polskich elit naukowych. Becoming transnational professional. ed. Scholar Wydawnictwo Naukowe, Warszawa (in print).

Wagner, I. (2010b). Konstruowanie "międzynarodowej” tożsamości badacza nauk biologicznych. w: Procesy tożsamościowe; red. Konecki Krzysztof, Kacperczyk Anna; (in print), Poland: Uniwersytet Łódzki.

Westby, D. L. (1960). The career experience of the symphony musician. Social Forces, 38, 223-230.

Ziman, J. (1987). Knowing everything about nothing. Specialisation and change in scientific careers. Cambridge: Cambridge University Press.

Zuckerman, E. W., Kim, T.-Y., Ukanwa, K., \& von Rittman, J. (2003). Robust identities or nonentities? Typecasting in the feature-film labor market. American Journal of Sociology, 108(5), 1018-1074. 